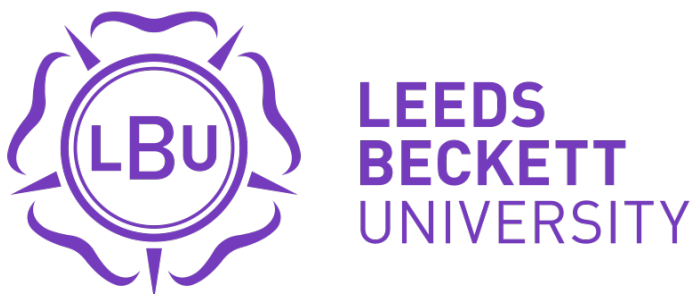

\section{Citation:}

Irving, $\mathrm{H}$ (2014) The birth of a politician: Harold Wilson and the bonfires of controls, 1948-9. Twentieth Century British History, 25 (1). 87 - 107. ISSN 0955-2359 DOI: https://doi.org/10.1093/tcbh/hws044

Link to Leeds Beckett Repository record:

https://eprints.leedsbeckett.ac.uk/id/eprint/2324/

Document Version:

Article (Updated Version)

The aim of the Leeds Beckett Repository is to provide open access to our research, as required by funder policies and permitted by publishers and copyright law.

The Leeds Beckett repository holds a wide range of publications, each of which has been checked for copyright and the relevant embargo period has been applied by the Research Services team.

We operate on a standard take-down policy. If you are the author or publisher of an output and you would like it removed from the repository, please contact us and we will investigate on a case-by-case basis.

Each thesis in the repository has been cleared where necessary by the author for third party copyright. If you would like a thesis to be removed from the repository or believe there is an issue with copyright, please contact us on openaccess@leedsbeckett.ac.uk and we will investigate on a case-by-case basis. 


\title{
The Birth of a Politician: Harold Wilson and the Bonfires of Controls,
} 1948-9

\begin{abstract}
:
This article uses a detailed examination on the 1948 and 1949 Bonfires of Controls to reassess Harold Wilson's development as a politician and examine the broader relationship between popular politics and economic policy. Whilst acknowledging the continued importance of the latter within Wilson's selfidentification as a modernising 'specialist', it contends that these events are best viewed as representing the birth of a professional politician. It will show that, although economically motivated, there was a marked disparity between each Bonfire's illusion and reality. Far from being entirely rational, each announcement straddled the gap between politics and economics. Within a post-war political landscape that had seen debates about controls become increasingly emotive, Wilson used the Bonfires to seize advantage. As a result, they can be seen to signify the point of his development from a self-identified professional economist to an astute political actor.
\end{abstract}

Key Words: Wilson; Politics; Planning; Controls

In the eyes of his detractors, Harold Wilson was too clever by half. Wilson, the unexpected Labour leader who went on to win four General Elections, is often regarded as a master of political deception. ${ }^{1}$ As Prime Minister, a homely Yorkshire accent, Gannex jacket and signature pipe softened his image and were deployed to provide balance to his rhetorical stress on modernity and economic planning. Yet the guise appeared to be a partial construction. A wartime colleague later recollected a polished

\footnotetext{
${ }^{1}$ For a particularly vehement appraisal see, The Macmillan Diaries, Vol. II, ed. P. Catterall (London, 2011), 541.
} 
academic tongue, his opponents pointed to a preference for cigars and his critics hinted at a 'seamy private and business life'. ${ }^{2}$ Wilson's legacy has been regarded as similarly illusory, with particular scorn reserved for the apparent failure to deliver on the widespread modernisation promised by his famous invocation of the 'white heat of the scientific revolution'. For David Edgerton, whose research has charted technological change throughout the twentieth century, this failure was all the more damming given that Britain had been the 'scientific and technological powerhouse of Western Europe' in 1960 and endured a relative decline during the Wilson years as his government grappled with its spending commitments. ${ }^{3}$ Such accusations have been levelled from across the political spectrum: with those on the left as uneasy about his political manoeuvring as those on the right. Indeed, during the period of internal factionalism that preceded his ascent to party leadership, Wilson appeared obsessed with his career, ideologically ambivalent and politically opportunistic. All of which stood at odds with an ideasfocused tradition and - in the words of Timothy Heppell - 'created an image of deviousness and disloyalty'. ${ }^{4}$

Wilson's reputation and political legacy have recently undergone something of a resurgence. In the years following his abrupt departure from public life, historians have tested his contemporaries' judgements and, especially after Ben Pimlott's seminal biography, have sought to place his actions within their proper context: with greater focus placed upon an understanding of what occurred, rather than simple praise or condemnation. ${ }^{5}$ Alongside this, and building upon contentions put forward by

\footnotetext{
${ }^{2}$ Peter Catterall, ‘Anatomising Wilson: Ben Pimlott’, Contemporary Record, 7 (1993), 322.

${ }^{3}$ David Edgerton, 'The "white heat” revisited: the British government and technology in the 1960s', Twentieth Century British History, 7 (1996), 53-54.

${ }^{4}$ Timothy Heppell, ‘The Labour Party leadership election of 1963: explaining the unexpected election of Harold Wilson’, Contemporary British History, 24 (2010), 152.

${ }^{5}$ Jim Tomlinson, The Labour Governments 1964-70, Vol. III: Economic Policy (Manchester, 2004), viii and Glen O’Hara and Helen Parr, 'Introduction: the fall and rise of a reputation', Contemporary British History, 20
} (2006), 295-302. 
Pimlott and Richard Coopey in an influential revisionist essay, there has been a notable reconsideration of Wilson's political economy - often dubbed 'Wilsonism'. Despite differences in emphasis, Ilaria Favretto, Glen O'Hara, Noel Thompson, Andrew Blick and Duncan Tanner have all argued that the attention paid to growth and modernisation in the run up to 1964 should be regarded as more than simple rhetoric. ${ }^{6} \mathrm{~A}$ more nuanced appraisal can even be detected within accounts that continue to present Wilsonism as something of an illusion. Steven Fielding, for example, analysing the 1964 election from a 'new political history' perspective, has argued that Wilson's strategy was more complicated than a simple 'catch all' revisionism. Instead, he maintains that it built upon foundations laid by Hugh Gaitskell and offered a relatively cautious programme that 'looked backwards almost more than it peered forwards'. ${ }^{7}$ Such an approach explicitly sets out to challenge a high political orthodoxy. Nonetheless, it should also be noted that - even when approached from such a position Wilsonism is seen to have offered a degree of compromise whilst maintaining a distinctly 'socialist' agenda. ${ }^{8}$

\footnotetext{
${ }^{6}$ Ilaria Favretto, ““Wilsonism” reconsidered: Labour Party revisionism 1952-64’, Contemporary British History, 14 (2000), 54-80; Glen O’Hara, “'Dynamic, exciting, thrilling change”: the Wilson government’s economic policies, 1964-70', Contemporary British History, 20 (2006), 386; Noel Thompson, ‘The Fabian political economy of Harold Wilson', in P. Dorey (ed.), The Labour Governments 1964-70 (London, 2006), 53-72; Andrew Blick, 'Harold Wilson, Labour and the machinery of government', Contemporary British History, 20 (2006), 357 and Duncan Tanner, 'Richard Crossman, Harold Wilson and devolution, 1966-70: the making of government policy’, Twentieth Century British History, 17 (2006), 545-578.

${ }^{7}$ Steven Fielding, 'Rethinking Labour’s 1964 campaign', Contemporary British History, 21 (2007), 310. See also David Horner, 'The road to Scarborough: Wilson, Labour and the scientific revolution', in R. Coopey, S. Fielding and N. Tiratsoo (eds), The Wilson Governments 1964-70 (London, 1993), 48.

${ }^{8}$ Thompson, 'The Fabian political economy of Harold Wilson', 62 and Heppell, 'The Labour Party leadership election', 156. For a high political appraisal of 1950s see Robert Crowcroft, 'The 'high politics' of Labour Party factionalism, 1950-5’, Historical Research, 81 (2008), 679-709.
} 
As is already evident, these most recent analyses remain almost exclusively focused on Wilson's period in Downing Street or as Labour Party leader. There has, despite a broader interest in his resignation from Cabinet alongside Nye Bevan in April 1951, been no further re-examination of Wilson's career before this point. Instead, the historiography of his formative years remains little changed from that surveyed by Pimlott and Philip Ziegler at the beginning of the 1990 s. ${ }^{9}$ Given that Pimlott had no access to Wilson's private papers, Ziegler maintained that most of the earliest had been destroyed and both dismissed the detailed use of governmental sources, a crucial part of Wilson's contextual history has arguably been missed. ${ }^{10}$ Perhaps more importantly, even the most recent have remained tacitly bound by the same framework of politics within which Wilson has been traditionally judged. Indeed, although seeking to de-politicise Wilson, the focus on Wilsonism as an ideology has implicitly lent weight to the view that political manoeuvre must in itself be regarded as deviant and that those engaged in it are inherently devious. This article offers an alternative view. It does not denigrate the charm of politics, but seeks to better understand Wilson's development as a politician. To do so, it focuses on his understanding of economic planning and his role, as President of the Board of Trade, in the 1948 and 1949 Bonfires of Controls. It begins by briefly setting out the Bonfires' content and development. From this, it moves to their historiographical importance before considering how they embodied Wilson's emergence as an astute political actor. It will argue that the Bonfires offer a unique vantage from which to analyse the nature of Wilsonism and suggest that this should be regarded as both a style and a coherent political philosophy.

\footnotetext{
${ }^{9}$ Coopey does mention the importance of Wilson's wartime experience but devotes little space to its analysis and, whilst devoting considerable attention to planning, Favretto begins her analysis in 1952.

${ }^{10}$ Catterall, ‘Anatomising Wilson’, 325 and Anthony Seldon, ‘Anatomising Wilson: Philip Ziegler’, Contemporary Record, 7 (1993), 345.
} 
Harold Wilson set out his first Bonfire to the House of Commons on 4 November 1948. The announcement, delivered as a response to a Parliamentary question, represented the largest relaxation of physical controls since the government had famously 'tightened belts' the previous year. With it, regulations covering over sixty commodities, which had necessitated 200000 different permits, were consigned to ashes. ${ }^{11}$ Having hinted at such a move a week earlier, the announcement was timed so that its press would coincide with the nation's Guy Fawkes' celebrations. In line with Wilson's intentions, the move was widely supported and even won plaudits from usually hostile commentators. The Daily Telegraph, to give one example, noted that it was 'clearly a step in the right direction' ${ }^{12}$ In the months that followed, Wilson continued on this course by announcing further deregulation. On 31 January 1949, for instance, it was announced that consumer restrictions were to be removed from most woollen goods. ${ }^{13}$ Just six weeks later, Wilson and his wife appeared in front of the press to declare that the entire clothes rationing scheme had ended and symbolically tore their coupon books in two. ${ }^{14}$ Following this theatrical flourish, Wilson's actions culminated when a second Bonfire was announced to Parliament on 22 March 1949. Extending upon the November announcement, this blaze removed a further 900000 licences and released twenty five more materials from quantitative control. ${ }^{15}$ Taken together, these highly visible announcements consigned over one hundred pieces of legislation, the requirement for a million licences, restrictions covering almost 130

\footnotetext{
${ }^{11}$ Parliamentary Debates (Commons), 457, 4 Nov 1948, 112-120.

${ }^{12}$ Daily Telegraph, 5 Nov 1948.

${ }^{13}$ Parliamentary Debates (Commons), 460, 31 Jan 1949, 1385-6.

${ }^{14}$ Henry Pelling, The Labour Governments, 1945-51 (London, 1984), 223.

15 Parliamentary Debates (Commons), 463, 22 Mar 1949, 212-20.
} 
different categories of material, and 1300 jobs to ashes. They were, for The Times, a significant 'clearing [of] the jungle of controls'. ${ }^{16}$

Wilson's actions were the last stage of a process that had begun on 5 November 1947 at the very first meeting of a newly inaugurated Government Organisation Committee (GOC). Chaired by Sir Edward Bridges, the Treasury's Permanent Secretary and Head of the Civil Service, the GOC had recommended then that an urgent interdepartmental review of controls should be undertaken as there was no 'up to date' information about their usage. After much discussion, it was decided that department-led investigations should be conducted within the Board of Trade, Ministry of Supply, Ministry of Food, Ministry of Fuel and Power and Ministry of Agriculture. ${ }^{17}$ Unlike earlier attempts, the resulting reviews were conducted by independent Examiners, were overseen by an official Coordinating Committee (CC) and were entirely concerned with the mechanics of the controls apparatus; it was planned that a second committee would be formed at a later date to look into the issues 'thrown up' by the Examiners from a policy-orientated perspective. ${ }^{18}$ The Board of Trade, responsible for the vast majority of industrial controls, was central to this investigation and appointed Lawrence Merriam, a former wartime Plastics Controller, on a full-time basis from 26 February 1948. The Board had been particularly keen make such an appointment. Indeed, its Permanent Secretary, Sir John Henry Woods, had provided much of the GOC's impetus and had drawn its attention to overlapping restrictions, wasted manpower and a 'widespread feeling that many controls ... create hampering frictions and delays' in a frank memorandum circulated in early December. ${ }^{19}$ As he would later admit publically during an address to the Institute of Public Administration, the main problem was that there was little

\footnotetext{
${ }^{16}$ The Times, 5 Nov 1948.

${ }^{17}$ Kew, The National Archives (TNA): PRO, T 222/636, Bridges, '’Relations between Government departments and trade and industry', c. 17 Dec 1947.

${ }^{18}$ TNA: PRO, T 222/636, Bridges, 'Review of controls’, 15 Jan 1948.

${ }^{19}$ TNA: PRO, T 222/213, Woods, 'Review of controls’, 9 Dec 1947.
} 
time to plan ahead or 'examine in the necessary detail the many controls which the Board of Trade administers' ${ }^{20}$ Merriam's appointment offered a chance to do just that.

The investigation undertaken after February 1948 was primarily focused upon the Board of Trade's complex licencing procedure for the control of scarce materials. The licencing scheme, like the majority of industrial regulations operated at the time, had been introduced during the course of the Second World War as a means of directing production and continued to be based upon Defence Regulation 55 of the original 1939 Emergency Powers (Defence) Act. ${ }^{21}$ Akin to a consumer rationing scheme, it worked by requiring private firms to hold either 'acquisition' or 'disposal' licences for those materials being controlled. Like most other controls operated during this period, the responsibility for granting licences differed between materials but tended to be held by quasi-autonomous agencies working on behalf of the department. Regardless of which body was responsible, the process involved the consideration of individual licence requests in line with available supplies and overall departmental priorities regarding production. ${ }^{22}$ As each request included a schedule of production that indicated at end use, this theoretically allowed for production to be planned from Whitehall without direct government intervention. Nonetheless, as Woods had supposed, Merriam's investigation drew attention to a number of inconsistencies brought about by the increasingly anachronistic use of wartime legislation. A particularly vivid example was found in his discovery that the continued licencing of vacuum flasks necessitated the administration of 125000 licences per annum, cost the Board of Trade over $£ 10000$ and involved a grand total of 131 staff whilst failing to meet any of its objectives. ${ }^{23}$ This was emblematic of a system that was later characterised by J.C.R.

\footnotetext{
${ }^{20}$ John Woods, 'Administrative problems of the Board of Trade', Public Administration, 26 (1948), 85-91.

${ }^{21}$ This was redrafted to become the Supplies and Service (Transitional Powers) Act in 1945.

22 Jack Stafford, 'British war controls - an economic comment', The Manchester School, 11 (1940), 142-62.

${ }^{23}$ TNA: PRO, BT 64/4298, Interdepartmental Meeting, 22 Dec 1947 and Merriam to Helmore, 14 Jun 1948.
} 
Dow, who worked as a governmental economic advisor before writing one of the first economic histories of this period, as loose and incredibly cumbersome. ${ }^{24}$

Wilson had been confronted with this situation from the moment that he was appointed President of the Board of Trade on 28 September 1947. The 'gaps and faults' were summarised by Alec Cairncross, another future historian then working as a civil servant, in a forceful twenty two page report that began with the warning that 'none of the instruments [worked] properly'. ${ }^{25}$ Having previously worked alongside Cairncross as a wartime economic 'specialist', not to mention his experience as a junior minister at the Board of Trade, Wilson was careful to present himself as particularly well suited to undertake the challenge of rationalisation. In fact, from humble beginnings as a statistician plotting the control of potatoes, he had become a leading advisor on the allocation of coal and had been responsible for a staff of 350 by the end of the conflict. ${ }^{26}$ This first-hand experience helps to explain why the Board were so keen to push for an investigation. Indeed, despite Woods' public intervention - which has led Bernard Alford, Rodney Lowe and Neil Rollings to attribute the Bonfires to orthodox laissez-faire attitudes within the department - it was Wilson who initially approached the Chancellor about the need to 'streamline' the system and Cairncross who was charged with organising the process of review. ${ }^{27}$ Far from pushing the issue, Woods' would even complain to the GOC that:

\footnotetext{
${ }^{24}$ J.C.R Dow, The Management of the British Economy 1945-60 (London, 1964), 168 and 172.

${ }^{25}$ TNA: PRO, T 222/213, Cairncross, ‘Export Promotion and “Controls”', 8 Oct 1947, 14.

${ }^{26}$ Philip Ziegler, Wilson: The Authorised Life of Lord Wilson of Rievaulx (London, 1995), 33.

${ }^{27}$ B.W.E. Alford, R. Lowe and N. Rollings, Economic Planning 1943-1951: A Guide to Documents in the Public Records Office (London, 1992), 989; Oxford, Bodleian Library, MS CASTLE, 228, Cairncross, ‘President’s morning meeting review of controls', 3 Nov 1947 and TNA: PRO, T 223/213, Bridges to Gilbert, Proctor and Simpson, 30 Oct 1947.
} 
I am being very severely heckled by the President, who is most anxious to press on ... He will certainly not take kindly to any suggestion that the Board of Trade should delay its own plans. ${ }^{28}$

Crucially, however, Wilson's rationale was explained in purely economic terms. As he noted in late 1949, controls wasted manpower and 'featherbedded' inefficient firms by removing competition and establishing quotas based upon pre-war production figures. ${ }^{29}$ With this critique of arbitrariness, he echoed many other former specialists. ${ }^{30}$

$-11-$

The above paragraphs have shown that, when viewed from an administrative perspective, the Bonfires appear relatively uncontroversial. Their flames, as Merriam was later forced to admit, were confined to the 'dry wood that makes easy burning'. ${ }^{31}$ Nonetheless, the Bonfires have become regularly cited points of reference within the history of the immediate post-war period. To understand why, a consideration of their context is vital. From an economic perspective, these years are defined by attempts to control economic development. Some of this was an inevitable reaction to the challenges posed by the transition from war to peace. But, as the Labour Party had pledged in the run up to its 1945 election victory, it also represented an attempt to deliver 'a comprehensive economic policy' that would allow the government to 'plan from the ground up'. ${ }^{32}$ Using wartime experience to

\footnotetext{
${ }^{28}$ TNA: PRO, T 223/213, Woods to Bridges, 4 Dec 1947.

${ }^{29}$ Oxford, Bodleian Library, MS WILSON, c.1102, Wilson, 'Public and private enterprise’, 13 Dec 1949 and The Economist, 26 Mar 1949.

${ }^{30}$ John Jewkes, Ordeal by Planning (London, 1948).

${ }^{31}$ TNA: PRO, T 230/319, Merriam, 'Final report to the President on the examination of controls', 23 Feb 1950.

${ }^{32}$ Labour Party, Let Us Face the Future (London, 1945), 4.
} 
vindicate calls for greater peacetime intervention, a technical pamphlet entitled The Case for Nationalisation and Control explained that this would allow the guidance of industry without necessitating total state ownership. ${ }^{33}$ Although it was stressed that their application would be democratic, economic controls were, in the words of Stephen Brooke, presented as 'the building blocks of socialism'.${ }^{34}$ With echoes to the 'White Heat' of 1964, Richard Toye has argued that this was a 'great political trump card' as Britain moved towards an uncertain future..$^{35}$ Any political advantage was, though, relatively short lived. Indeed, during 1947 , the government's ability to plan was severely undermined by a succession of crises that began with a shortage of coal, led to a run on the pound and ended with a strict policy of domestic austerity. ${ }^{36}$ These failings ensured that controls became symbols of a post-war reality that stood at odds with popular expectations of peace. ${ }^{37}$ As shown by Ina Zweiniger-Bargielowska, whose consumer focused research has linked the social and political developments of this period, they became electoral liabilities that were easily exploited by a resurgent Conservative Party. ${ }^{38}$

\footnotetext{
${ }^{33}$ Labour Party Research Department, The Case for Nationalisation and Control (London, 1945), 18.

${ }^{34}$ Stephen Brooke, Labour's War: The Labour Party during the Second World War (Oxford, 1992), 248 and Labour Party, Let Us Face the Future, 2 and 5.

${ }^{35}$ Richard Toye, The Labour Party and the Planned Economy, 1931-1951 (Woodbridge, 2003), 185.

${ }^{36}$ Geoffrey Fry, The Politics of Decline: An Interpretation of British Politics from the 1940s to the 1970s

(Basingstoke, 2005), 96 and Alex J. Robertson, The Bleak Mid-Winter:1947 (Manchester, 1987), 17.

${ }^{37}$ Hugh Dalton, High Tide and After: Memoirs, 1945-1960 (London, 1962), 347; Peter Hennessey, Having it So Good: Britain in the Fifties (London, 2007), 10 and K.O. Morgan, Britain Since 1945: The Peoples' Peace
} (Oxford, 2001), 68.

${ }^{38}$ Ina Zweiniger-Bargielowska, Austerity in Britain: Rationing, Controls and Consumption, 1939-1955 (Oxford, 2000), 203 and 'Rationing, austerity and Conservative Party recovery after 1945', The Historical Journal, 37 (1994), 173-197. 
A critique of controls certainly formed a crucial part of the Conservatives' arsenal. Winston Churchill's party had, during the 1945 General Election, infamously campaigned against 'a permanent system of bureaucratic controls' that it portrayed as being 'abhorrent to the British [idea] of freedom' ${ }^{39}$ During a contest that was overshadowed by his claim that Labour's planning 'would have to fall back on some form of Gestapo', two thirds of the Conservative Party's election addresses included negative references to controls. ${ }^{40}$ Crucially, and despite the controversy that surrounded Churchill's clumsy broadcast, this strategy was continued into the second half of 1940s. In spring 1946, for example, adopting a more consumer-orientated perspective as the threat of bread rationing sparked vociferous protests from housewives and bakers, one party publication depicted a housewife surrounded by an atomic cloud of restrictions and noted that her hostility could 'explode at any moment' ${ }^{41}$ Eighteen months later, in November 1947, the party's Tactical Committee began to collate examples of 'ridiculous controls' that could be used as 'platform ammunition' against the Labour government. ${ }^{42}$ This was continued in July 1949, when, four years after the 1945 results had become known, the Conservative Party launched its campaign for a forthcoming General Election with the publication of a detailed 68 page manifesto that described the party's main purpose as being to 'free the productive energies of the nation from the trammels of overbearing state control' ${ }^{43}$ That October, addressing a packed Earl's Court Empress Hall, in front of an estimated 10000 delegates, Churchill

\footnotetext{
${ }^{39}$ Richard Toye, ‘Winston Churchill’s “Crazy Broadcast”: party, nation and the 1945 Gestapo speech’, Journal of British Studies, 49 (2010), 655-680.

${ }^{40}$ R.B. McCallum and Alison Readman, The British General Election of 1945 (London, 1947), 101.

${ }^{41}$ James Hinton, 'Women and the Labour vote’, Labour History Review, 57 (1992), 59-66 (59) and Ina

Zweiniger-Bargielowska, 'Bread Rationing in Britain, July 1949-July 1948', Twentieth Century British History, 4 (1993), 57-85 (60).

${ }^{42}$ Oxford, Conservative Party Archives (CPA), CCO 4/4/59, 'Ridiculous controls’, 25 Feb 1948.

${ }^{43}$ Conservative Central Office (CCO), This is the Road: The Conservative and Unionist Party's Policy (1950), 22.
} 
presented this statement to the Conservatives' Annual Conference and accused Labour of having insulted 'the rights and liberties of Englishmen'. ${ }^{44}$ Embodied by the call to 'set the people free', the opportunity was used to repeat earlier claims that planning would inevitably lead to totalitarianism and reinforce his party's self-association with liberty. In the words of Richard Austen 'Rab' Butler, the party's chief policy-maker, controls had become symbolic of a fundamental 'choice between two ways of life' ${ }^{45}$

The Conservative Party's protracted campaign was significant as it successfully linked an abstract argument for liberty with more tangible worries. Controls were, thus, not simply chastised as symbols of state interference but also for holding back enterprise and subverting respect for the law. Like accusations of totalitarianism, these arguments can be traced back to earlier - more academic critiques like Freidrich Hayek's Road to Serfdom and John Jewkes' acerbic Ordeal by Planning. ${ }^{46}$ Nonetheless, as demonstrated by Mark Roodhouse, the latter point had become particularly important in the autumn of 1948 when allegations of misconduct and corruption uncovered a political scandal at the Board of Trade. Following intense press speculation, a special Tribunal of Inquiry under Mr Justice Lynskey eventually found that John Belcher, a Parliamentary Secretary, and George Gibson, a director at the Bank of England, had accepted gifts in exchange for granting industrial licences. Although the quantities involved were relatively insignificant, the case served to focus attention onto the Board's complex apparatus of control and allowed for a continued critique of its allegedly

\footnotetext{
${ }^{44}$ British Pathé, UN 2187E, 'Tory Party Conference (Unused Material)', 14 Oct 1949 and The Times, 15 Oct 1949.

${ }^{45}$ Ina Zweiniger-Bargielowska, 'Consensus and consumption: rationing, austerity and controls after the war', in H. Jones and M. Kandiah (eds), The Myth of Consensus: New Views on British History, 1945-64 (Basingstoke, 1996), 91.

${ }^{46}$ Jewkes, Ordeal by Planning, 4 and F.A. Hayek, The Road to Serfdom (London, 1946), 54-75.
} 
criminogenic nature. ${ }^{47}$ Speaking just days after the scandal had broken, Cyril Garbett, the Archbishop of York, warned that the 'fog of petty and irritating restrictions' presented a potent threat to the moral underpinnings of British society. ${ }^{48}$ The Archbishop's speech, which gained national coverage in the press, was seized upon by the pugnacious Conservative MP John Boyd-Carpenter in a pamphlet that was designed to foster discussion amongst party activists. Accepting that evasion had become widespread, he pointed to the 'socially disastrous' consequences of a system that was out of line with public opinion. 'Children who see their parents break one law without shame', he noted, 'will be predisposed themselves to break others' ${ }^{49}$ For Churchill, speaking in the debate following Belcher's resignation, the moral of the story was clear, 'if you destroy a free market, you create a black one'. ${ }^{50}$

When viewed against this ideologically charged debate - one in which controls were used as a proxy for actions that could be described as either 'socialist', 'totalitarian' or 'immoral' - Wilson's pledge to remove every control apart from 'those which are essential' has often been interpreted as representing a definite shift in emphasis. Indeed, within a literature that has broadly accepted that physical controls were necessary 'building blocks' for economic planning, and which has tended to agree with Brooke that this was 'a notable ... casualty' of the period, the Bonfires have been drawn into a network of network of conflicting arguments surrounding the extent to which their relaxation should be seen as a retreat for an administration committed to recreate Britain as a 'Socialist Commonwealth'. ${ }^{51}$ Sitting alongside the picture later described by Zweiniger-Bargielowska, others,

\footnotetext{
${ }^{47}$ Mark Roodhouse, 'The 1948 Belcher affair and Lynskey Tribunal', Twentieth Century British History, 13 (2002), 384-411 and Edward Smithies, The Black Economy in England since 1914 (Dublin, 1984), 97.

${ }^{48}$ Daily Mail, 3 Nov 1948.

49 John Boyd-Carpenter, About Bureaucracy: Some Facts for Discussion Groups (London, 1949), 8.

${ }^{50}$ Financial Times, 4 Feb 1949.

${ }^{51}$ Stephen Brooke, 'Problems of “Socialist Planning”: Evan Durbin and the Labour Government of 1945’, The Historical Journal, 34 (1991), 687-702; Alan Budd, The Politics of Economic Planning (London, 1978), 58 and 72; Alec Cairncross, Years of Recovery: British Economic Policy, 1945-51 (London, 1985), 329-332; John
} 
including Kenneth Morgan and Pimlott, have argued that Wilson's actions must be seen as an attempt to appease an increasingly hostile society. ${ }^{52}$ They were, for Dow, an attempt to imbue the removal of minor controls - regulations which served 'no economic function' - with an undeserved sense of drama. ${ }^{53}$ Both sets of ideas drew upon a long lineage. The Fabian economist G.D.N. Worswick, for example, whose influential edited collection began the economic literature on this period, argued in 1952 that any developments within the apparatus of controls had to be viewed in line with their increasingly political nature. ${ }^{54}$

A number of Wilson's colleagues viewed the Bonfires through a similar lens. For example, on 12 November 1948, following a week of broadly supportive newspaper coverage, an article in Tribune warned its readers that 'whenever the Tories are pleased with something the Government has done, it is time for Socialists to sit up and pay attention'.$^{55}$ Six months later, during a debate on the Labour Believes in Britain policy statement at the party's 1949 Annual Conference, many began to do just that. The MP Maurice Webb, for example, warned that the Bonfire could become a 'funeral pyre of social justice' whilst Barbara Castle, who worked with Wilson at the Board of Trade and would later become one of his most trusted colleagues, claimed that policy was being led by economic advisors who 'are not Socialists ... and think the only way of getting back to normal is by abandoning physical

Callaghan, Socialism in Britain since 1884 (Oxford, 1990), 156; Dow, The British Economy 1945-60 , 11; Stephen Haseler, The Gaitskellites: Revisionism in the British Labour Party, 1951-64 (London, 2005), 96-7 and 57-8; Kevin Jefferys, The Labour Party since 1945 (Basingstoke, 1993), 22 and Toye, Labour and the Planned Economy, 216-220.

${ }^{52}$ K.O. Morgan, Labour People: Leaders and Lieutenants, Hardie to Kinnock (Oxford, 1987), 170 and Ben Pimlott, Harold Wilson (London, 1992), 127.

${ }^{53}$ Dow, The Management of the British Economy, 49.

${ }^{54}$ G.D.N. Worswick, 'Direct controls', in G.D.N Worswick and P. Ady (eds), The British Economy, 1945-1950 (Oxford, 1952), 282.

${ }^{55}$ Tribune, 12 Nov 1948. 
controls'. ${ }^{56}$ The growing dissatisfaction amongst the party's left wing was encapsulated in the 1950 pamphlet Keeping Left which warned against an 'epidemic of decontrol' and suggested that Britain may have even avoided devaluation had it not been for the Bonfires ${ }^{57}$ It is not the intention of this article to dwell on these debates. But it should be noted that the parameters within which they occur can be brought into question. In fact, addressing similar questions from a slightly different perspective, the entire notion of retreat has recently been criticised for constructing an almost ahistorical version of events. ${ }^{58}$ Moreover, in maintaining a focus upon the broader meaning attributed to controls, much of the exiting scholarship has also overlooked a reality that was, in the words of Neil Rollings, 'more complex and ambiguous than that often presented'.$^{59}$ But, most importantly, by casting judgement on the Bonfires for being politically motivated, it has done little to explain how Wilson was able to make the announcements politically viable.

This omission is somewhat surprising when one considers that the Bonfires were built upon a latticework of obsolete industrial licences. They would, as The Economist noted, 'be felt with most relief by the businessman' ${ }^{60}$ Although their findings must be viewed with a degree of caution, this view was borne out by contemporary opinion polls. Indeed, even at the height of the 1945 General Election campaign, Mass Observation (M-O) had found that only 5 per cent of its sample of 396

\footnotetext{
${ }^{56}$ Labour Party, Report of the $48^{\text {th }}$ Annual Conference (1949), 141-2 and 161.

${ }^{57}$ R. Acland et al, Keeping Left (London, 1950), 15.

${ }^{58}$ Catherine Ellis, 'Letting it slip: the Labour Party and the 'Mystical Halo' of Nationalisation, 1951-64', Contemporary British History, 26 (2012), 47-71 and Ben Jackson, 'Revisionism reconsidered: "propertyowning democracy” and egalitarian strategy in post-war Britain', Twentieth Century British History, 16 (2005), 416-440 (417).

${ }^{59}$ Neil Rollings, 'Butskellism, the post-war consensus and the managed economy’, in H. Jones and M. Kandiah (eds), The Myth of Consensus: New Views on British History, 1945-64 (Basingstoke, 1996), 112.

${ }^{60}$ The Economist, 13 Nov 1948.
} 
respondents thought that controls were amongst the three most important issues being discussed. ${ }^{61}$ This apparent lack of resonance helps to explain why the British Institute of Public Opinion (BIPO), the British franchise of the Gallup Organisation and pioneer in the use of quantitative sample surveys, did not even include a category to cover 'controls' until $1948 .{ }^{62}$ Even Woods, when asked by Bridges to consider how the results of Merriam's investigations should be announced on 30 July 1948, remained adamant that the subject was one that the public were 'only remotely interested' in. ${ }^{63}$ Crucially, and notwithstanding their libertarian rhetoric, his fairly pessimistic view was shared by a despondent Conservative Party that conceded in early 1948 that its campaign against controls had so far failed because 'The wage-earner has little need to fill up forms for licences permits or passports' ${ }^{64}$ The key question for consideration, therefore, is that of how Wilson was able to translate a subject which bore so little relation to everyday lives into one of popular political debate.

- III-

This question is complicated by the fact that the Bonfires were little more than parliamentary updates. Wilson made it clear that they were part of a 'policy which has been frequently stated' and each included numerous regulations that had already been removed. ${ }^{65}$ Even the decision to bundle each announcement was not, in itself, entirely surprising given that the government had always intended to make a statement half way into the departmental investigations. ${ }^{66}$ Yet the decision to quantify the

\footnotetext{
${ }^{61}$ Sussex, Mass Observation Archive (M-O), File Report 2265, ‘General Election’, Oct 1945.

${ }^{62}$ For examples, George Gallup (ed.), The Gallup International Public Opinion Polls: Great Britain 1937-1975, Vol. 1 (New York, 1976), 115-6; 135-6; 148-9; 160; 165; 175 and 187.

63 TNA: PRO, T 228/304, Minutes: WPP(48)4, 30 July 1948.

${ }^{64}$ CPA, ACP 1/1/3, 'Memorandum with reference to propaganda for wage earners', c. Jan 1948.

65 Parliamentary Debates (Commons), 457, 4 Nov 1948, 114.

66 TNA: PRO, T 228/304, Bridges to Proctor, 30 Jun 1948 and BT 64/4227, Kennedy to Binney, 28 Aug 1948.
} 
Bonfire in terms of licence requests removed was far from rational. The claim was over 130000 licences higher than the figure given by a letter of explanation sent to Sir Stafford Cripps, the Chancellor of the Exchequer, and had not been included in the first draft of Wilson's speech. ${ }^{67}$ Moreover, despite the apparent expansion of his scope, the estimated number of jobs that would be saved remained surprisingly low. The imprecise figure of 30-40 was, in fact, exactly the same as that given to a GOC meeting before the addition of the extra licences. ${ }^{68}$ The apparent disparity led to questions from the Treasury; Bridges, who feared that it would be exposed by The Economist, referred to the issue as a potential scandal and demanded an explanation. ${ }^{69}$ The reason soon became apparent. In a personal letter from Woods, sent on 2 December, he was informed that the low manpower saving could be explained by the fact that the vast majority of the licences included were those covering the distribution of vacuum flasks. ${ }^{70}$ This scheme was, as noted above, symbolic of the confusion inherent within the system. Even so, the decision to describe each individual request for a permit as a 'control' certainly exaggerated the announcement's importance. There was 'no doubt', Merriam admitted, '[that] this bonfire had a better press that its actual content deserved' ${ }^{.1}$

Wilson would have been well aware of this point. Indeed, Merriam's 'Half Term Report', which was presented at the beginning of September, had ominously noted that it would be almost impossible to distinguish between essential and inessential controls before the end of his investigation. ${ }^{72}$ This outcome could have been anticipated from the very outset. The GOC had, in fact, explicitly called for the departmental Examiners to avoid the licensing system, which it described as

\footnotetext{
${ }^{67}$ TNA: PRO, T 222/215, Wilson to Cripps, 29 Oct 1948.

68 TNA: PRO, T 222/215, Note on GOC meeting, 27 Oct 1948.

69 TNA: PRO, T 222/215, Bridges to Woods, 16 Nov 1948.

70 TNA: PRO, T 222/215, Woods to Bridges 2 Dec 1948 and Johnston to Armstrong 11 Nov 1948.

71 TNA: PRO, T 222/215, Merriam, ‘Merriam’s November Report’, 1 Dec 1948.

72 TNA: PRO, T 222/214, Merriam, 'Half Term Report', 8 Sept 1948.
} 
being 'of minor importance', and focus their efforts on more important organisational and structural problems. ${ }^{73}$ The Board of Trade's decision to ignore this advice left the investigation beset by internal uncertainties and the CC remained adamant that no one person fully comprehends the whole system ${ }^{\prime 74}$ Wilson's approach to clothes rationing caused similar stirrings of unease. Indeed, following initial ration changes made during the late spring and summer of 1948 , when some miscellaneous goods and all footwear was 'taken off the ration', Robert Hall, the director of the Economic Section, complained to Edwin Plowden, the Chief Planning Officer, that the decision had been taken without consultation and cast 'doubt [over] whether our talk of planning is a reality or not' ${ }^{75}$ Almost a year later, and just days before the second Bonfire was announced, similar fears were repeated by Douglas Jay. There was, he carefully noted, a real risk that the Bonfires gave 'an impression of general relaxation' that stood at odds with the government's overall policy. ${ }^{76}$ These fears were widely shared and even Merriam called for an 'alternative technique'. ${ }^{77}$ It is clear, however, that the March announcement was deliberate and had gained support from the highest level. Indeed, that January, during a Cabinet discussion, Clement Attlee had called on his Ministerial team to ensure that they were able to get 'credit for a good story'. His comment was supported by Wilson, who endeavoured to do just that. ${ }^{78}$

The presentational devices adopted by Wilson - such as the symbolic tearing of his ration book - certainly stood in stark contrast to the more subdued line adopted by the other ministries. He had, in fact, been 'anxious to get ahead' from the outset and had hoped to include notices of decontrol in

\footnotetext{
${ }^{73}$ TNA: PRO, T 222/636, Bridges, 'Review of Controls’ and 'Relations between Government Departments and Trade and Industry’, 15 Jan 1948.

${ }^{74}$ TNA: PRO, T 222/37, Armstrong, ‘Controls’, c. Oct 1948.

75 TNA: PRO, T 230/152, Hall to Plowden, 31 May 1948.

${ }^{76}$ TNA: PRO, T 222/216, Jay to Proctor, 17 Mar 1949.

77 TNA: PRO, T 228/304, Merriam, 'First Term Report', 15 Mar 1949.

${ }^{78}$ TNA: PRO, CAB 128/15, CM(49)5, 20 Jan 1949 and CAB 195/7, CM(5)49, 20 Jan 1949.
} 
his departmental press conferences from January $1948 .{ }^{79}$ Although this was not to be the case, the CC noted a year later that his 'spirit of incendiarism' had shown the Board of Trade to be 'thoroughly Bonfire minded' ${ }^{80}$ It all seemed to be something of a departure for a man who prided himself on being a professional economist and had been described as a 'brilliant young civil servant' in $1945 .{ }^{81}$ Wilson's emergence as a political figure had been somewhat unavoidable; compared with wartime Whitehall, the Board of Trade was a very public responsibility and his position as the youngest Cabinet Minister of the twentieth century added a degree of interest. Yet it is clear that he had also taken care to cultivate his public image. His infamously technical speeches were, for instance, meticulously prepared so as to avoid repetition and his young family had even taken part in a filmed interview for British Pathé just weeks after he moved to the Board of Trade. ${ }^{82}$ Wilson, it must be noted, was not a particularly natural performer in front of the camera. Even so, and despite ministers being warned off newsreel appearances by Herbert Morrison, the technique was adopted again in 1949 to announce the eventual abolition of the clothes rationing scheme. ${ }^{83}$ Physically, too, Wilson had moved closer to the political sphere by leaving academic north Oxford for the London suburb of Hampstead. ${ }^{84} \mathrm{His}$ emergence as a public figure had been confirmed in July 1948 when comments made to a political rally about a shortage of children's footwear - and an alleged claim that most children attending his primary school had done so without shoes - were seized upon by the press. Coinciding with the

\footnotetext{
79 TNA: PRO, T 222/213, Woods to Bridges, 20 Jan 1948.

80 TNA: PRO, T 228/304, Proctor, 'Note by the Chairman’, 20 Apr 1949.

${ }^{81}$ Manchester Guardian, 30 Sept 1947 and News Chronicle quoted in Ziegler, 48.

82 The interview involved Wilson answering questions from an armchair in a studio designed to look like a suburban house and was interspersed with shots of his wife and son engaged in various domestic activities. See British Pathé, 47/80, 'Harold Wilson at home' and 'Work or want week makes the headlines'.

${ }^{83}$ William Crofts, Coercion or Persuasion? Propaganda in Britain after 1945 (London, 1989), 225 and British Pathé, UN 1978 C and 49/22, 'Goodbye to coupons - Wilson’.

${ }^{84}$ Pimlott, Harold Wilson, 113-4.
} 
decision to remove controls over these items, the story caused much debate and the volume of letters received by Wilson' secretary even led to the creation of a distinct 'Barefoot File'. ${ }^{85}$ Set against these developments, the Bonfires appear as inherently political acts.

A similar picture emerges when one considers the timing of each announcement. The desire to wait until Merriam had been able to produce an interim statement was certainly an important factor in determining this aspect of the first Bonfire's presentation. Nonetheless, given the nature of their announcement, the choice of date must also be viewed in line with its context. ${ }^{86}$ This is especially important given that the period was dominated by the allegations of corruption explored by Roodhouse. Indeed, although the story was eventually confined to the actions of three men, the length of time taken to launch the Tribunal of Inquiry coupled with an initial absence of information fostered an atmosphere of intense speculation. ${ }^{87}$ When placed against this chronology, it is evident that the November Bonfire was particularly well timed. The first hint of an announcement came, with the Chancellor's assent secured, on the evening of Friday 29 October. Speaking at an open meeting in Golders Green, the working day before the Tribunal was due to open, Wilson ensured that Monday's newspapers would include a reference to possible decontrol as well as potential corruption. The Bonfire itself, announced on 4 November, also offered some positive political news at the start of campaigning in an Edmonton by-election precipitated by the death of Labour's Evan Durbin. Although Wilson would later claim that such contests were fought on 'record and policy', his decision to announce the abolition of clothes rationing on the eve of another crucial poll (the Sowerby Bridge byelection forced by Belcher's resignation) led many to accuse him of blatant trickery. ${ }^{88}$ The

\footnotetext{
${ }^{85}$ Bodleian Library, MS WILSON, c.1722, Correspondence re: Wilson’s remarks on Barefoot Children.

${ }^{86}$ TNA, T 222/214, Merriam, 'Merriam’s Half Term Report', 8 Sept 1948, 3-4.

${ }^{87}$ Roodhouse, 'The 1948 Belcher affair', 385-6.

88 Parliamentary Debates (Commons), 462, 14 Mar 1949, 1741.
} 
Conservative frontbencher Harold Macmillan summed up the mood when he made a joking wish for 'another by-election so that we can get some more meat' ${ }^{89}$

Although Labour held both seats, the exact relationship between each announcement and broader public opinion is impossible to gauge. Taken together, the Bonfires did coincide with a growing optimism about the national economy and a broader swing in support for the government that saw satisfaction ratings reach a twelve month high in March 1949. ${ }^{90}$ However, despite helping to foster a narrative of normalisation, many controls were only removed because rising prices and a lack of disposable income had led to a slackening of domestic demand. This was especially true of clothing. The scheme, which was the only to have a direct impact on the consumer, had been gradually undermined by rising prices and a lack of disposable income with the existence of significant gluts an open secret shared by many in trade. ${ }^{91}$ The situation was such that, by January 1949 , over 70 per cent of respondents to the Government's Social Survey believed themselves to be constrained by cash and not coupons. ${ }^{92}$ The decision to finally abolish the scheme - described as being part of 'a great experiment' - was only taken once an Advisory Council made up of representatives from the trade and consumer groups was clear that consumption levels would not increase. As a report conducted by the Economic Section concluded, it would have very little impact on ordinary housewives ${ }^{93}$ It is nevertheless interesting that Wilson's experiment should have included the use of such research. Indeed, the use of advisory bodies was novel whilst the Social Survey investigations on behalf of the Board remained something of an anomaly during a period in which polling tended to be regarded as

\footnotetext{
${ }^{89}$ Daily Telegraph, 15 Mar 1949.

90 TNA: PRO, T 222/215, Merriam, 'November report', 1 Dec 1948 and Gallup, Public Opinion Polls Vol I, 171-195.

${ }^{91}$ See for examples, Daily Mail, 4 Nov 1948 and Yorkshire Post, 15 Mar 1949.

92 TNA: PRO, RG 23/104, ‘Survey of knowledge and opinion about the economic situation', Jan 1949.

93 TNA: PRO, T 230/152, ‘The first two days of freedom from Clothes Rationing’, 17 Mar 1949.
} 
an unreliable intrusion into the political system. ${ }^{94}$ They were, though, just one part of a broader attempt to show that decontrol was simply a matter of common sense. Indeed, somewhat paradoxically, the Bonfires' real political significance was that they represented an attempt to depoliticise controls.

Wilson, drawing upon his self-identification as a 'specialist', as well as the views expressed by the Board of Trade's industrial representatives and in the many letters of complaint it received from members of the public, keenly acknowledged the failings inherent within a system that had never been properly planned. The entire issue of controls, he maintained, was simply one 'on which too much doctrinaire rubbish is talked' ${ }^{95}$ This was a central part of his argument. Addressing the criticism from Labour's left wing in late 1949, for instance, he maintained that it was difficult to 'see any retreat from socialism' in the controls that had been removed. ${ }^{96}$ It was perhaps more important, as he explained to Parliament on 22 March, that his actions placed the government 'a few steps ahead of the Opposition' ${ }^{97}$ This tactic must be understood as an attempt to nullify a central component of the Conservative Party's political strategy. Indeed, by adopting a broad definition of controls - one which imbued an outdated system of licensing with an undue sense of significance - the Bonfires seized the initiative by removing the validity of their claims. Speaking in the debate of the 1948 King's Speech, for example, exactly a year after Churchill had first called for the government to 'set the people free',

\footnotetext{
${ }^{94}$ Laura Beers, 'Whose opinion? Changing attitudes towards opinion polling in British politics, 1938-1964', Twentieth Century British History, 17 (2006), 177-205 (194-8); Joe Moran, 'Mass Observation, market research, and the birth of the focus group', Journal of British Studies, 47 (2008), 827-851; Mark Roodhouse, “"Fish-andchip intelligence”: Henry Durant and the British Institute of Public Opinion', Twentieth Century British History, advanced access (2012), 1-25.

${ }^{95}$ Bodleian Library, MS WILSON, c.1098, speech to Federation of Curriers, Light Leather Tanners and Dressers, 15 Mar 1949.

${ }^{96}$ Bodleian Library, MS WILSON, c.1102, Wilson, 'Public and private enterprise’, 13 Dec 1949.

${ }^{97}$ Parliamentary Debates (Commons), 463, 21 Mar 1949, 214.
} 
Wilson argued that he was making progress before the Conservatives had even finished writing 'the list of controls which they would remove'.$^{98}$ Six months later, in a debate on the Budget, he proclaimed that 'the days ... when [the Conservative Party] could suggest that all our production problems could be solved with a slogan' had long passed. ${ }^{99}$ By capitalising upon the same ambiguity that had allowed the Conservatives to link controls with freedom, Wilson had successfully conjured an illusion of change that was used to highlight their complete absence' of an alternative policy. ${ }^{100}$ It was a deft move.

$-I V-$

It should not be forgotten, however, that these public statements were only one part of a more complicated story. There was, in fact, a continuing economic motivation to Wilson's actions and the changes he made to the apparatus of controls were always designed to improve productivity in the first instance. Far from representing a retreat, the Bonfires offered a chance for clarification with Merriam's findings promoting a broader process of rethinking. At a party level, this saw Wilson join a number of Labour's younger intellectuals - including Evan Durbin and Peter Shore - on a new Privately Owned Industry policy subcommittee in early spring 1948. The group, which would produce a reference paper on controls, would eventually produce ideas that formed the backbone of Labour's 1950 manifesto. Given Merriam's stress on the need to find an alternative to the wartime system, it was symbolic that they began their first meeting by considering a memorandum that called on government to 'regard industry not as a very small boy who must be told sharply what to do and how not to do it, but as a grown up partner'. ${ }^{101}$ The process of rethinking also drew upon a number of

\footnotetext{
98 Parliamentary Debates (Commons), 456, 17 Sept 1948, 404.

${ }^{99}$ Bodleian Library, MS WILSON, c.1104, 'Budget and Economic Survey debate’, 11 Apr 1949.

100 Bodleian Library, MS WILSON, c. 1107, ‘Speech to Knowsley’, 10 Jul 1949.

${ }^{101}$ Manchester, Labour Party Archives (LPA), LPRD, RD 69, Miller, 'Socialism and private enterprise’, Oct 1947, 7 and RD 170, 'Draft: Controls’, Oct 1948.
} 
academic sources with Worswick offering his professional view and party leaders jointly hosting a series of secretive 'experts conferences' - which brought together a diverse range of delegates from Keep Left's lan Mikardo to Jewkes and Cairncross - with the Fabian Society during the course of 194850. ${ }^{102}$ This was all indicative of a broader shift in emphasis and a growing realisation that successful planning was dependent upon more than the nominal control provided by the current licensing schemes. The theme continued into the autumn and was eventually encapsulated in an influential paper by Michael Young - the head of Labour's Research Department - which duly recognised that many of the controls currently employed would be unnecessary by the early 1950s and sought to stimulate thoughts regarding alternatives. ${ }^{103}$

Wilson's own ideas on this future development were encapsulated in May 1950 in a frankly written call-to-action entitled 'The State and Private Industry'. Wholly based upon his experience at the Board of Trade, this memorandum virulently attacked existing forms of control and lamented past failures to put something more suitable in their place. ${ }^{104}$ Even so, Wilson remained adamant that there were more efficient ways to plan and sought to answer some of the questions that Young had raised earlier. His constructive proposals promoted a multifaceted approach that centred on the use Development Councils, research and development, the identification of 'key firms', and targeted investment as a means of encouraging an active partnership between the government and private firms. ${ }^{105}$ Despite his Bonfire-mindedness, this indicative vision was matched by a continued commitment to 'basic' strategic controls. It was, to quote Wilson in 1964 , to be 'planning with

\footnotetext{
${ }^{102}$ LPA, LPRD, RD 167, Worswick, 'A Policy for private enterprise', Oct 1948 and Martin Francis, Ideas and Policies Under Labour, 1945-1951 (Manchester, 1997), 10.

${ }^{103}$ LPA, LPRD, RD 147, Young, 'Policy for private industry', Sept 1948.

104 TNA: PRO, CAB 124/1200, Wilson, ‘Covering note to the memorandum: the state and private industry',
} May 1950, 2.

105 TNA: PRO, CAB 124/1200, Wilson, ‘The state and private industry’, May 1950, 6-7 and 10-14. 
teeth' ${ }^{106}$ Although these recommendations were considered in detail by the government and at a separate party consultation set up at Attlee's personal request, they were never fully adopted and even a Board of Trade working group questioned whether they could be achieved in practice ${ }^{107}$ It is , therefore, unsurprising that Wilson's paper has remained somewhat overlooked by historians who have tended to focus on his diagnosis that its subject was a 'vacuum of socialist thought' rather than the remedies he put forward. ${ }^{108}$ Nonetheless, embodying a Wilsonian economic thought, 'The State and Private Industry' was an apt piece of self-reflection and represented a real attempt to resolve a dilemma that had hindered progress throughout the 1940s.

The focus on co-operation with private industry certainly impacted upon a new generation of Labour thinkers and formed an important theme within R.H.S Crossman's influential collection of New Fabian Essays published in $1952 .{ }^{109}$ The emphasis on 'key firms' would also remerge within the revisionist policy statements Industry and Society and Plan for Progress before being rediscovered by Wilson in $1963 .{ }^{110}$ During a period that is so often characterised as being beset by internal debates, it must also be noted that these ideas cut across the boundary between 'Bevanites' and 'Gaitskellites'. Most importantly, in a clear reference to the political culture of the 1940s, 'The State and Private Industry' also represented a distinct shift towards a consumer-orientated focus. ${ }^{111}$ Indeed, drawing heavily upon ideas put forward by Young and Christopher Mayhew, a Junior Minister at the Board of

\footnotetext{
${ }^{106}$ Harold Wilson, Purpose in Politics: Selected Speeches by Harold Wilson (London, 1964), 47.

${ }^{107}$ LPA, General Secretaries Papers (GS), IND/70, Wilson, ‘The state and private industry’ and correspondence i -viii and TNA: PRO, BT 64/743, 'Positive economic controls’, f.1.

${ }^{108}$ Jim Tomlinson, 'Planning: debate and policy in the 1940s', Twentieth Century British History, 3 (1992), 154$174(161)$.

${ }^{109}$ Austin Albu, 'The organisation of industry', in R.H.S. Crossman (ed.), New Fabian Essays (London, 1952), $121-142$.

${ }^{110}$ Favretto, “"Wilsonism” reconsidered', 64 and 74.

${ }^{111}$ TNA: PRO, CAB 124/1200, Wilson, ‘Covering note’.
} 
Trade during Wilson's tenure, it called for a 'Consumer's Charter' to ensure greater consumer protection and representation. ${ }^{112}$ As he would as Prime Minister, Wilson demonstrated a conception of the electorate as being 'ordinary, decent folk whose first thought about every government ... is how [they] will affect them and their families' ${ }^{113}$ The public, he explained, tended to vote as consumers and there was 'every danger that once again many electors will vote against us' ${ }^{114}$ Skilfully drawing upon the very context that had allowed his Bonfires to appear significant whilst promoting a policy that remained avowedly 'socialist' - and, within which, certain controls continued to play an important role - Wilson had matched political style with political philosophy.

$-\mathrm{V}-$

It is clear that the ambiguity surrounding the controls system and Labour's vision of democratic planning presented a number of opportunities. This article has shown how Wilson was able to actively exploit this confusion in order to remove a central facet of the Conservative Party's appeal during a period of intense party political competition. Nevertheless, there were limits to his actions and any plaudits were relatively short-lived. Indeed, only two days after the first blaze was lit, the Daily Mail claimed that the Bonfires were being used as a smokescreen to placate voters whilst Labour sought to impose its doctrinaire vision of socialism; Britain, it declared, would 'get lollipops - but lose liberty'. ${ }^{115}$ As Bridges feared, its scale also drew a number of questions with The Economist satirically noting that 'it ought not to have needed an official examiner to find out that the permit scheme for

\footnotetext{
${ }^{112}$ Hilton, Consumerism, 100-105 and 154 (see also consumer protection papers BT 258/352-6).

${ }^{113}$ Edward Short, Whip to Wilson (London, 1989), 110 and Pimlott, Harold Wilson, 33-6.

114 TNA: PRO, CAB 124/1200, Wilson, ‘Covering note’.

${ }^{115}$ Daily Mail, 6 Nov 1948.
} 
the distribution of thermos flasks had become a complete farce'. ${ }^{116}$ The societal impact of the removal of industrial controls was similarly limited and, though the Bonfires may have promoted a growing optimism about the national economy, the Social Survey continued to report a widespread perception that people were personally struggling to cope. ${ }^{117}$ Against a transitional context permeated by continued crises, decontrol was a somewhat unsustainable tactic. However, it was a tactic that was based upon a rational economic appraisal and, when viewed against the immediate political context, one that made sense. It is, after all, worth remembering that 'a week is a long time in politics' ${ }^{118}$

If the Bonfires should be viewed as neither an outright success nor an outright failure, it is thanks to Wilson that they remain potent. Through them, he turned rational economics into a political weapon. Like his Bonfires, Wilson was an ambiguous figure. On the one hand, he appeared as a rational technocrat committed to making a mixed economy work, on the other a rising politician who exploited a system characterised by continued ambiguity to outmanoeuvre an Opposition that had sought to associate itself with decontrol. The six months between September 1948 and March 1949 marked a crucial stage in his political development. It was at this point that the self-styled 'specialist' began to gain a reputation as an astute political player. In exposing a degree of uneasiness within his own party and earning him criticism for apparent tendency to 'score points', the Bonfires also offered something of a precursor to his future. ${ }^{119}$ Indeed, as argued in a very different context by O'Hara and Helen Parr, Wilson's ideas and actions appeared to be somewhat ahead of their time. ${ }^{120}$ As noted by Pimlott, it all seemed to be a long way from the familiar alternative: life as a junior academic writing

\footnotetext{
116 The Economist, 13 Nov 1948.

117 TNA: PRO, RG 23/105, 'Survey of knowledge and opinion about the economic situation', Mar 1949.

118 This saying was, of course, famously attributed to Harold Wilson. See The Economist, 13 Oct 1972.

${ }^{119}$ Financial Times, 20 Sept 1948.

${ }^{120}$ O’Hara and Parr, 'Fall and rise', 300.
} 
essays and articles that no one was likely to read. ${ }^{121}$ The Bonfires may not have signified the death of a modernising 'professional economist', but they did herald the birth of a politician. As such, they provide an insight into a high level understanding of popular politics during the immediate post war and the complex relationship between this and public opinion more broadly defined. They were, in short, symbolic of a nascent Wilsonism and suggest the need for a historical approach that pays attention to both aspects thereof.

${ }^{121}$ Pimlott, Harold Wilson, 113. 